\section{Adverse events associated with antimicrobial compounds in a general hospital in Chile}

\author{
MÓNICA KYONEN ${ }^{1, a}$, ALBERTO FICA ${ }^{2,3}$, CLAUDIA RIVAS ${ }^{4, a}$, \\ FELIPE TORRES ${ }^{5, a}$, DIEGO REYES ${ }^{6, a}$, CLAUDIA SCHEINOST $^{7}$,a
}

\section{ABSTRACT}

Background: Antimicrobial compounds are associated with a wide range of adverse events $(A E)$ and some of them can be potentially preventable. Aim: To characterize AE associated with antimicrobial compounds. Patients and Methods: Retrospective analysis of AEs reported to the National Pharmacological Surveillance System from 2014 to 2017 in a regional hospital. Severity, causality and preventability were analyzed. Results: Sixty events were observed in 56 patients aged 2 months to 96 years. Cases were registered mostly in hospitalized patients. The most frequent AEs were skin disorders (56.7\%), followed by hepatobiliary (13.3\%), and CNS events (10\%). Blood, kidney, respiratory gastrointestinal and immunological disorders were less frequently registered, including cases with anaphylactic shock and Stevens-Johnson syndrome (SJS). Causal analysis indicated a definitive association in 8.3\%, probable in 70\% and possible in 22\%. Skin lesions were mostly associated with beta-lactams, hepatobiliary disorders with antituberculosis drugs and CNS manifestations with carbapenems. Cutaneous, neurological, and hepatobiliary events appeared at a median of 4, 2.5 and 10.5 days after starting the medication, respectively. AEs were managed with withdrawal of the suspected drug (83.3\%) and other auxiliary therapies. AEs were categorized as severe in $22 \%$ and one case with SJS had a fatal outcome (1.7\%). Preventability analysis revealed $25 \%$ of potentially avoidable events. Conclusions: Antimicrobial AE involved a wide diversity of compounds, occurred in different hospitalization units, affected patients of a wide age range and attacked different systems or organs. An important fraction was potentially avoidable.

(Rev Med Chile 2021; 149: 1119-1128)

Key words: Anti-Infective Agents; Causality; beta-Lactams; Drug-Related Side Effects and Adverse Reactions; Hepatitis.

\section{Efectos adversos asociados al uso de antibióticos en un hospital general}

Antecedentes: Los compuestos antimicrobianos están asociados a una amplia gama de eventos adversos (EA) y algunos de ellos pueden ser potencialmente prevenibles. Objetivos: Caracterizar los EA asociados a compuestos antimicrobianos. Pacientes y Métodos: Análisis retrospectivo de EA reportados al Sistema Nacional de Farmacovigilancia desde 2014 la 2017 en un

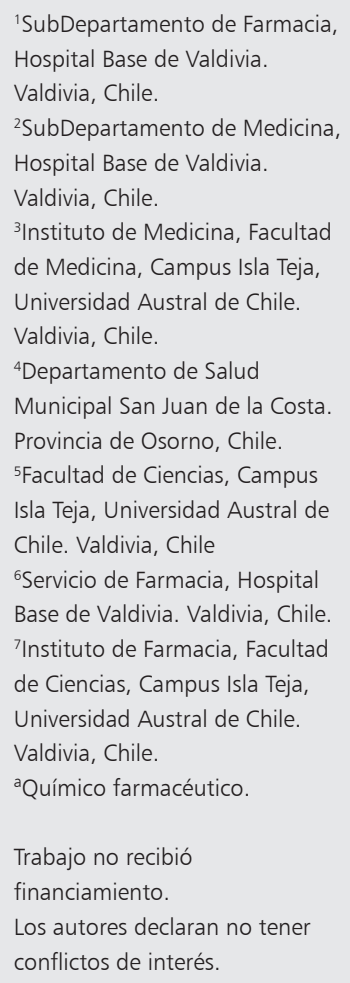

Recibido el 12 de mayo de 2020, aceptado el 19 de mayo de 2021.

\section{Correspondencia a:}

Dr. Alberto Fica

SubDepartamento de Medicina Hospital Base de Valdivia, Chile. Bueras 1003. Valdivia, Chile. albertoficacubillos@gmail.com 
hospital regional. Se incluyó un análisis de gravedad, causalidad y de posible prevención. Resultados: Se observaron 60 eventos en 56 pacientes de 2 meses a 96 años. Los casos se registraron principalmente en pacientes hospitalizados. Los EA más frecuentes fueron los trastornos de la piel (56,7\%), seguidos de los hepatobiliares $(13,3 \%)$ y del sistema nervioso central (10\%). Los hematológicos, renales, respiratorios, gastrointestinales e inmunológicos se registraron con menos frecuencia, incluidos casos con shock anafiláctico y sindrome de Stevens-Johnson (SSJ). El análisis de causalidad indicó una asociación definitiva en $8.3 \%$, probable en $70 \%$ y posible en $21.7 \%$. Las lesiones cutáneas se asociaron principalmente a betalactámicos, los trastornos hepatobiliares a fármacos antituberculosos y las manifestaciones del SNC a carbapenémicos. Los eventos cutáneos, neurológicos y hepatobiliares se presentaron en una mediana de 4, 2,5 y 10,5 días después de iniciar el medicamento, respectivamente. Los EA se manejaron con el retiro del fármaco sospechoso (83,3\%) y otras terapias auxiliares. Los EA se clasificaron como graves $(21,7 \%)$ y un caso con SSJ tuvo un desenlace fatal (1,7\%). Un 25\% de los eventos fue potencialmente evitable. Conclusiones: Los resultados de este trabajo revelan que los AE por antimicrobianos involucran una amplia diversidad de compuestos, ocurren en diferentes unidades de hospitalización, afectan a pacientes de un amplio rango de edad y atacan diferentes sistemas u órganos.

Palabras clave: Antiinfecciosos; Causalidad; beta-Lactamas; Efectos Colaterales y Reacciones Adversas Relacionados con Medicamentos; Hepatitis.

A ntimicrobials compounds have reduced the morbidity and mortality of many infectious diseases since their appearance in the last century. However, they are not free from adverse effects that can generate new morbidity that sometimes can be fatal. Description of these adverse events (AE) is usually approached from the perspective of the affected system or organ (skin lesions, hepatotoxicity, etc.), by the type or family of compounds (i.e. beta-lactams), pathologies involved (HIV/AIDS), place of occurrence (general room, ICU) or age of patients (children, adults) ${ }^{1-9}$. A complementary way of analyzing this problem is by specific therapeutic groups such as antimicrobials ${ }^{7,8}$, which despite being involved in several AE have not been systematically evaluated in previous publications in Chile. This approach allows knowing the spectrum of associated adverse reactions, causal relationship of the suspected molecule, severity, preventability, management and outcome. We decided to carry out a local investigation with these objectives; the results of which we believe contribute to the knowledge of these complications.

\section{Patients and Methods}

\section{Definition of AE and study design}

We defined an AE as the appearance of any unwanted adverse effect temporarily associated with the use of an antimicrobial compound at usual doses, whether for diagnostic or prophylactic $\mathrm{use}^{10}$. A retrospective design was applied using the reports of notifications (by passive methodology) of AE made to the National Pharmacovigilance System from years 2014 to 2017 in our institution. Events involving antimicrobial compounds of oral or parenteral use among hospitalized or ambulatory patients were included.

\section{Case analysis}

For each reported AE, we collected patient's demographic data, comorbidities, immunosuppressive drugs use, allergic symptoms, previous adverse reactions, hospitalization unit where the event occurred, system or organ involved, antimicrobial compound suspected, route of administration and time elapsed until appearance. Management of the AE and its outcome was also recorded. Causal analysis was made using the 
Karch-Lasagna method and preventability by a previous described method ${ }^{10,11}$. The work only includes $\mathrm{AE}$ where the causal analysis assigned a score in the definitive ( $\geq 8$ points), probable (6-7 points) or possible (4-5 points) categories. Events were also categorized as mild (digestive disorders, headache, tiredness, myalgia, compromised general condition, sleep disturbances), moderate (skin lesions, visual disturbances, tremors, urination problems, noticeable variation on mind or mental functions) or serious/lethal (life-threatening or fatal, AE leading to severe disability or invalidity or causing or prolonging hospitalization and birth defects).

\section{Ethical aspects}

This work was approved by the Comite de Ética Científico, Servicio de Salud Valdivia, Chile.

\section{Results}

\section{AE reported and patient characteristics}

Between years 2014 and 2017, 84 AE associated with antimicrobials were recorded. In 14 cases $(16.7 \%)$ an alternative cause for another drug or the underlying disease was identified and in 10 (11.9\%) there were incomplete or absent data, leaving 60 final events in which clinical information could be obtained (71.4\%). These $60 \mathrm{AE}$ involved 56 patients; one patient had 3 events in the same hospitalization, 2 patients had a double event and the remaining 53 only one (94.6\%). Patients were associated with a wide age range $(2$ months to 96 years) with a balanced distribution by gender and different comorbidities (mainly heart disease, diabetes mellitus, chronic kidney disease and leukemia/lymphoma), but a third did not present any of them (Table 1). Additionally, another third of patients presented immunosuppression either by drugs ( 5 patients, $25 \%$ of the group) or due to an underlying pathology, and $16.1 \%$ had a history of previous AEs (Table 1). Near 10\% has an allergic history. Patients affected by these AE were hospitalized in Units of different complexity, including the Emergency Unit and 2 cases were reported as outpatients (Table 1).

\section{Type of adverse reactions and eosinophilia}

The most frequent AE reported was skin involvement with rash in approximately half of the cases and most of the time of generalized type (Table 2). In 3 of the 34 cases, the rash was associated with mucosal involvement or bullous skin lesions, and in 2 of these 3 cases, the condition was classified as Stevens-Johnson syndrome (SJS) (3.3\% of all events) (Table 2 ). The second system affected was the liver with hepatitis, cholestasis, or mixed type. CNS followed in frequency mainly with seizures. The series also includes hematological disarrangements in all series and two anaphylactic events. Renal, respiratory, or gastrointestinal involvement was occasionally observed (Table 2). In total, 7 events were associated with eosinophilia $(>500 /$ $\mu \mathrm{L}), 5$ of them in skin lesions ( $16.7 \%$ of the cutaneous group), one in an anaphylactic shock and the other with anemia.

Table 1. General features of 56 patients evolving with adverse reactions associated to antimicrobial compounds. Hospital Base de Valdivia, 2014-2017

\begin{tabular}{|lc|}
\hline Variable & Results \\
\hline Age mean value (range) & 48 (2 months - \\
& 96 years) \\
Female gender $n$ (\%) & $30(53.6 \%)$ \\
\hline Comorbidities* & \\
Heart disease & $9(15.8 \%)$ \\
Diabetes Mellitus & $7(12.5 \%)$ \\
Chronic renal disease & $7(12.5 \%)$ \\
Leukemia /Lymphoma & $6(10.7 \%)$ \\
Solid neoplasms & $5(8.2 \%)$ \\
Chronic liver disease & $4(7.1 \%)$ \\
Chronic lung disease & $5(8.9 \%)$ \\
Autoimmune diseases & $5(8.9 \%)$ \\
Asthma & $1(1.8 \%)$ \\
HIV/AIDS & $1 \quad(1.6 \%)$ \\
Without comorbid conditions & $17(30.4 \%)$ \\
Immunesuppresion* & $20(35.7 \%)$ \\
Allergy (any kind) & $5(8.9 \%)$ \\
Previous drug-related adverse events & $9(16.1 \%)$ \\
Site & $22(39.3 \%)$ \\
Critical care unit & $6(10.7 \%)$ \\
General ward & $2(3.6 \%)$ \\
Emergency room & \\
Ambulatory & \\
\hline
\end{tabular}

*Non self-excluding conditions. 
Table 2. Organ and systems involved in $\mathbf{6 0}$ adverse events associated to antimicrobial compounds. Hospital Base de Valdivia, 2014-2017

\begin{tabular}{|c|c|}
\hline Organ or system involved & $\begin{array}{c}\text { Results } \\
\text { n (\%) }\end{array}$ \\
\hline Skin & $34(56.7 \%)$ \\
\hline Generalized rash ( 2 or more body sites) & 25 \\
\hline Stevens-Johnson syndrome & 2 \\
\hline Rash with bullous lesions & 1 \\
\hline Rash without specification & 6 \\
\hline Hepatobiliary & $8(13.3 \%)$ \\
\hline Hepatitis & 4 \\
\hline Cholestasis & 1 \\
\hline Mixed & 3 \\
\hline Central or peripheral nervous system & $6(10 \%)$ \\
\hline Seizures & 5 \\
\hline Agitation / anxiety & 1 \\
\hline \multicolumn{2}{|l|}{ Blood series } \\
\hline Thrombocytopenia & $3(5 \%)$ \\
\hline Neutropenia & $3(5 \%)$ \\
\hline Anemia & $1 \quad(1.7 \%)$ \\
\hline \multicolumn{2}{|l|}{ Renal } \\
\hline Acute renal injury & $1 \quad(1.7 \%)$ \\
\hline \multicolumn{2}{|l|}{ Immunological } \\
\hline Anaphylactic shock & $2(3.3 \%)$ \\
\hline \multicolumn{2}{|l|}{ Gastrointestinal } \\
\hline Nauseas/vomiting & $1 \quad(1.7 \%)$ \\
\hline \multicolumn{2}{|l|}{ Respiratory } \\
\hline Respiratory depression & $1 \quad(1.7 \%)$ \\
\hline Total & $60(100 \%)$ \\
\hline
\end{tabular}

\section{Antimicrobials involved}

The compounds mostly associated with adverse reactions were beta-lactams in about half of them, followed by anti-tuberculosis drugs, then glycopeptides (vancomycin) and quinolones. Other compounds were less frequently reported and in some cases by association of 2 or more antibiotics (excluding anti-tuberculosis drugs, Table 3).

\section{Causal analysis}

This analysis revealed a definitive association in 5 events $(8.3 \%)$, probable in $42(70 \%)$ and possible in the remaining 13 cases $(21.7 \%)$. Table 4 presents the causal analysis for skin lesions, showing the
Table 3. Antimicrobial compounds involved in 60 adverse events, Hospital Base de Valdivia, 2014-2017

\begin{tabular}{|lc|}
\hline Antimicrobial compound & Results n (\%) \\
\hline Beta-lactams & $29(48.3 \%)$ \\
\hline Anti-tuberculosis drugs* & $9(15 \%)$ \\
Glycopeptides & $7(11.7 \%)$ \\
Quinolones & $3(5 \%)$ \\
Metronidazole & $2(3.3 \%)$ \\
Oxazolidinones & $2(3.3 \%)$ \\
Cotrimoxazole & $1(1.7 \%)$ \\
Colistin & $1(1.7 \%)$ \\
Macrolydes & $1(1.7 \%)$ \\
Tetracyclines & $1(1.7 \%)$ \\
Two or more compounds** & $4(6.7 \%)$ \\
Total & $60(100 \%)$ \\
\hline
\end{tabular}

*Adverse event associated to one antituberculous drug in 6 cases, to 2 drugs in 2 events and to 3 compounds in one event; ${ }^{*}$ to imipenem + cotrimoxazole, vancomycin + ceftazidime in 2 events and to cotrimoxazole + levofloxacin + benzathine penicillin $\mathrm{G}$.

predominance of beta-lactams in the definitive and probable categories. Skin lesions were also associated with glycopeptides, quinolones, isoniazid, doxycycline, and different combinations of antimicrobials (Table 4). The 2 cases with SJS were related to ceftriaxone and the combination of vancomycin with ceftazidime (both possible). Hepatobiliary disorders were mostly associated with anti-tuberculosis drugs (Table 5). Hepatitis events were associated with isoniazid and/or pyrazinamide and cholestasis with rifampicin. Mixed disorders (cholestasis with hepatitis) were assigned to pyrazinamide or drug combinations (Table 5). No patients had history of liver damage and in any case doses were higher than those recommended per weight (data not shown). Age was not significantly higher in the group with this complication compared to the rest of the patients (Mann-Whitney non-parametric test, data not shown). For AE involving the CNS (Table 6), compounds associated with seizures, the most frequent manifestation in this group, were carbapenems, especially ertapenem and in one case 
Table 4. Causal analysis of 34 skin-related adverse events. Hospital Base de Valdivia, 2014-2017

\begin{tabular}{|c|c|c|c|c|}
\hline \multirow[b]{2}{*}{ Antimicrobial compound } & \multicolumn{3}{|c|}{ Causal relationship } & \multirow[b]{2}{*}{$\begin{array}{c}\text { Tota } \\
\mathbf{n}\end{array}$} \\
\hline & $\begin{array}{c}\text { Definitive } \\
\geq 8 \text { points } \\
n\end{array}$ & $\begin{array}{c}\text { Probable } \\
\text { 6-7 points } \\
\text { n }\end{array}$ & $\begin{array}{c}\text { Possible } \\
\text { 4-5 points } \\
\text { n }\end{array}$ & \\
\hline $\begin{array}{l}\text { Beta-lactams } \\
\text { Stevens-Johnson }\end{array}$ & 3 & 17 & $\begin{array}{c}1 \\
(1)\end{array}$ & 21 \\
\hline Glycopeptides & 1 & 3 & 1 & 5 \\
\hline Quinolones & 0 & 2 & 0 & 2 \\
\hline Anti-tuberculosis drugs & 0 & 1 & 0 & 1 \\
\hline Tetracyclines & 0 & 1 & 0 & 1 \\
\hline $\begin{array}{l}\text { Two or more compounds } \\
\text { Stevens-Johnson }\end{array}$ & 0 & 1 & $\begin{array}{l}3 \\
(1)\end{array}$ & 4 \\
\hline Total & 4 & 25 & 5 & 34 \\
\hline
\end{tabular}

Beta lactams: definitive (ceftriaxone 2 cases, meropenem 1 case); probable (ceftriaxone in 10 cases, penicillin in 2 cases, cefotaxime in 1, ceftazidime in 1, amoxicillin-clavulanate in 1, meropenem in 1, imipenem in 1); possible (ceftriaxone in 1). Glycopeptides (vancomycin): as indicated in the line. Quinolones: ciprofloxacin and levofloxacin, probable in 1 each. Antituberculous drugs: isoniazid (probable). Tetracyclines: doxycyclin probable in 1. Combinations: vancomycin + ceftazidime possible in 2, imipenem + cotrimoxazole possible in 1, cotrimoxazole + levofloxacin + benzathine penicillin $\mathrm{G}$ probable in 1 case. Stevens-Johnson cases (marked in parenthesis) were associated to ceftriaxone in 1 case and to the combination vancomycin + ceftazidime in another case.

Table 5. Causal analysis of hepatobiliary adverse events associated to different antimicrobial compounds. Hospital Base de Valdivia, 2014-2017

\begin{tabular}{|c|c|c|c|c|}
\hline \multirow[b]{2}{*}{ Antimicrobial compound } & \multicolumn{3}{|c|}{ Causal relationship } & \multirow[b]{2}{*}{$\begin{array}{c}\text { Total } \\
\text { n }\end{array}$} \\
\hline & $\begin{array}{c}\text { Definitive } \\
\geq 8 \text { points } \\
n\end{array}$ & $\begin{array}{c}\text { Probable } \\
\text { 6-7 points } \\
n\end{array}$ & $\begin{array}{c}\text { Possible } \\
\text { 4-5 points } \\
\text { n }\end{array}$ & \\
\hline \multicolumn{5}{|l|}{ Anti-tuberculosis drugs } \\
\hline Hepatitis* & 0 & 1 & 2 & 3 \\
\hline Cholestasis** & 0 & 1 & 0 & 1 \\
\hline Mixed $^{* * *}$ & 0 & 2 & 1 & 3 \\
\hline \multicolumn{5}{|l|}{ Macrolydes } \\
\hline Hepatitis**** & 0 & 1 & 0 & 1 \\
\hline Total & 0 & 5 & 3 & 8 \\
\hline
\end{tabular}

*Hepatitis due to pyrazinamide (probable in 1), pyrazinamide + isoniazid (possible in 2 cases). ${ }^{* *}$ Cholestasis secondary to rifampicin (probable in 1 event). ${ }^{* *}$ Mixed by pyrazinamide (probable in 2 cases) and by rifampicin + pyrazinamide + isoniazid (possible in 1 case). ${ }^{* * * *}$ Clarithromycin (probable in 1 case).

metronidazole. Ciprofloxacin was associated with an agitation-anxiety event.

AE compromised all hematological series. Thrombocytopenia (nadir 3.000-53.000/ $\mu \mathrm{L}$ ) was associated with linezolid (1 probable case), ceftriaxone (possible in 1 case) and vancomycin with ciprofloxacin (possible in 1 case). Neutropenia events (nadir 400-900/ $\mu \mathrm{L}$ ) also observed in 3 cases were associated with vancomycin, cloxacillin, and cefadroxil, all 3 as probable. The only reported case with anemia was assigned to linezolid (probable). Renal events with streptomycin-associated insu- 
Table 6. Causal analysis for CNS-related adverse events associated to antimicrobial compounds. Hospital Base de Valdivia, 2014-2017

\begin{tabular}{|lcccc|}
\hline Antimicrobial compounds & $\begin{array}{c}\text { Cefinitive } \\
\mathbf{2} \mathbf{8} \text { points } \\
\mathbf{n}\end{array}$ & $\begin{array}{c}\text { Causal relationship } \\
\text { Probable } \\
\mathbf{6 - 7} \text { points } \\
\mathbf{n}\end{array}$ & $\begin{array}{c}\text { Possible } \\
\mathbf{4 - 5} \text { points } \\
\mathbf{n}\end{array}$ & Total \\
$\begin{array}{l}\text { Seizures } \\
\quad \text { Carbapenems* }\end{array}$ & 0 & 3 & 1 & $\mathbf{n}$ \\
$\quad$ Metronidazole & 0 & 0 & 1 & 4 \\
$\begin{array}{l}\text { Agitation-anxiety } \\
\text { Ciprofloxacin }\end{array}$ & 0 & 1 & 0 & 1 \\
Total & 0 & 4 & 2 & 1 \\
\hline
\end{tabular}

*Ertapenem probable in 3, meropenem possible in 1.

fficiency was also observed in one probable case, anaphylactic shock in 2 cases (cotrimoxazole and ceftazidime, both as probable), one gastrointestinal event with nausea and vomiting due to metronidazole (definitive category), and an event of respiratory depression due to colistin (possible).

\section{Adverse effects onset}

Skin lesions presented within a median of 4 days (interquartile range [IQR] 1-6 days; range 0-20 days) with $41.2 \%$ in the first 72 hours. The 2 SJS events occurred at 5 days. The median onset for skin events was slightly higher than the elapsed time for neurological manifestations (median 2.5 days, IQR 1-5 days, range 1-12 days) although these differences were not significant (Mann-Whitney non-parametric test). On the other hand, hepatobiliary AE presented with a median of 10.5 days (Figure 1, IQR 8-17 days, range 2 to 28 days), a figure significantly higher than the onset time for skin or neurological lesions ( $\mathrm{p}=0.025$ by Mann Whitney test). For hematological conditions, the three thrombocytopenia events appeared between 1 and 9 days after antimicrobial initiation with their nadir 4-6 days later (Figure 2). Neutropenia presented between 5 and 65 days after initiation.

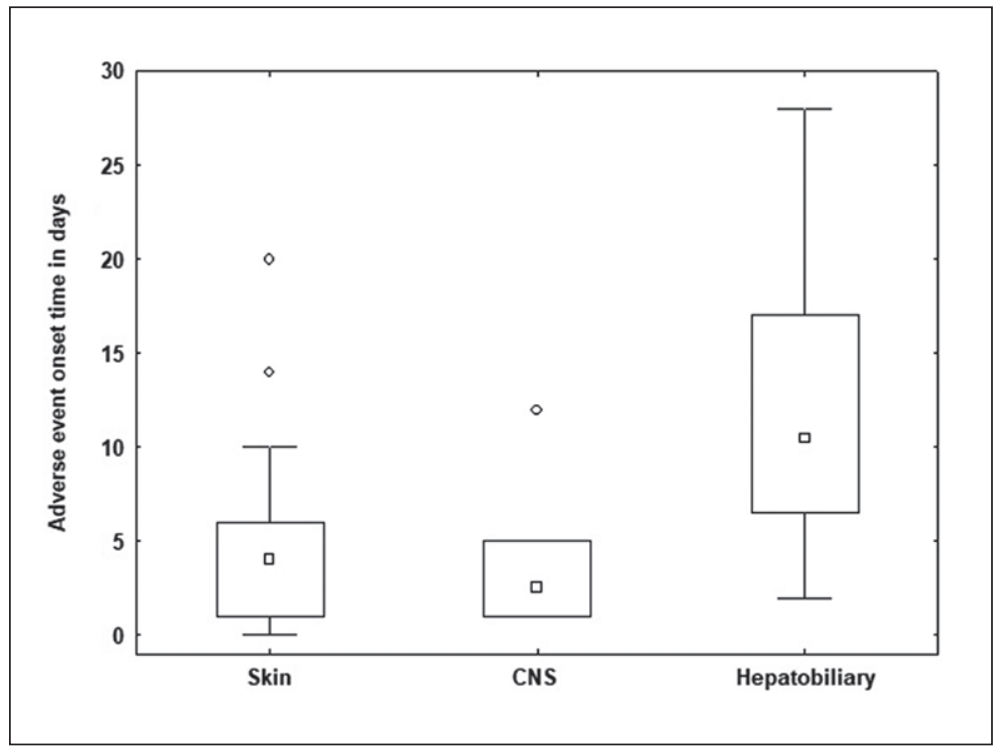

Figure 1. Box plot showing onset in days for cutaneous, central nervous system (CNS) and hepatobiliary adverse events. Median values are denoted by a square inside each box. Upper and lower borders of each box indicate the $25-75 \%$ interquartil range. Horizontal bars outside boxes show non-extreme maximal and minimal values, and open circles, extreme values. Onset of hepatobiliary adverse events were significantly later than values for skin and neurological events (see text). 


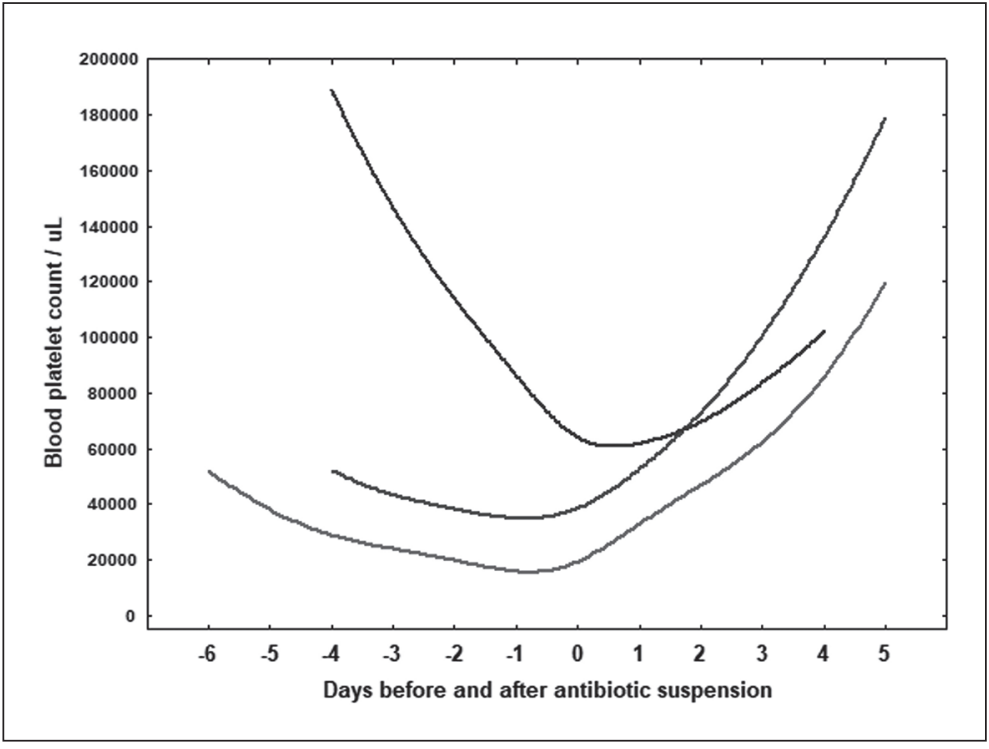

Figure 2. Platelet counts in 3 events of thrombocytopenia associates to antimicrobial compounds. Values were adjusted by the least square method. Zero indicates the day antibiotic was suspended.
The only anemia event was detected 8 days after starting linezolid. AE from other systems were observed at 24 hours in a gastrointestinal reaction, at 29 days for streptomycin and at 24 hours and 4 days in anaphylactic shock events.

\section{AE duration}

The longest events corresponded to hepatobiliary reactions that had a median duration of 24.5 days (range 6 to 37), followed by thrombocytopenia (median of 12 days, range 10 to 13 ), and then cutaneous events with a median of 6 days (range 0-39). In turn, the median for 3 neutropenia events was 4 days (range 4 to 18 ) and for the 2 anaphylactic events was 5.5 days (3 and 8 days). Shortest symptoms were associated with CNS with a median of 0 days (range $0-2$ days). The isolated event of anemia lasted 9 days, that of renal failure 30 days, the gastrointestinal event 1 day and the respiratory depression 12 days.

\section{AE management, severity, outcome and therapy change}

AEs were managed in different ways in 59 of the 60 reported events $(98.3 \%)$, mostly with suspension of involved drugs ( $\mathrm{n}=54$ events; $91.5 \%$ of the subgroup; $83,3 \%$ of the whole group). Additionally, 27 events received corticosteroids (45.8\% of the treated subgroup) and 29 antihistamines
(49.2\% of the subgroup). On the other hand, anticonvulsant therapy was indicated in the 5 events with seizures and connection to mechanical ventilation in the event of respiratory depression associated with colistin. Anemia linked to linezolid required transfusion as one of the events of thrombocytopenia. Corticosteroid therapy was used in patients with skin lesions but also in events of thrombocytopenia and anaphylactic shock.

$\mathrm{AE}$ were categorized as mild $(\mathrm{n}=2,3.3 \%)$, moderate in most cases $(\mathrm{n}=45,75 \%)$ and severe in $21.7 \%(\mathrm{n}=13)$. In all but one case there was a recovery from the adverse reaction (98.3\%). However, one event with SJS had a fatal outcome (1.7\% of events). Overall, AE forced to change the antimicrobial regimen in two thirds of cases ( $\mathrm{n}=39 ; 65 \%)$.

\section{Preventability analysis}

In 15 AEs ( $25 \%$ of the total), their appearance could have potentially been prevented. Six cases of rash could potentially have been avoided: one with a previous history of allergy to the same family of antimicrobials (beta-lactams), two cases without bacterial infection that justified their use, one with beta-lactams therapeutic duplication and one by vancomycin where the low prevalence in Chile of community-acquired infections by methicillin-resistant Staphylococcus aureus discourage 
its use. Finally, an event associated with penicillin in combination with other drugs for a possible streptococcal pharyngitis had already received adequate treatment. For 4 cases with seizures $(80 \%$ of the 5 reported cases) this complication could have been avoided after considering preexistence brain lesions or strokes in 2 cases, kidney failure without dose adjustment and redundant anaerobic coverage ( 1 each). Furthermore, the event of agitation/anxiety associated with quinolones could have been avoided by choosing another option for the patient's folliculitis. All of these conditions represent potential avoidable events linked to medical prescription.

Two anaphylactic shock events observed in this series, could also have been avoided by choosing another option to treat acne in one case (cotrimoxazole) or simply avoid its use in a case of imaging-ruled out pneumonia (ceftazidime). A lethal SJS case associated with ceftazidime and vancomycin, the use of the latter in community-acquired pneumonia had no epidemiological justification in Chile. Finally, anemia secondary to linezolid in a context of nosocomial pneumonia could have been avoided by choosing to keep tigecycline in use.

\section{Discussion}

Results of this work reveal that antimicrobial AE occur perceptibly in medical practice involving a wide diversity of compounds, occurring in different hospitalization units, affecting patients of a wide age range and attacking different systems or organs. Furthermore, some of them were serious, even fatal, and an important fraction is potentially avoidable. Its management usually requires the interruption of the suspected compound and sometimes auxiliary therapies. As shown, antimicrobial compounds of the same family are capable of causing adverse reactions in different systems.

Findings were obtained from a passive surveillance system known for its very low sensitivity ${ }^{2}$. However, they are relevant for their adequate characterization including a causal and preventability analysis, severity categorization, duration and management description.

AE with skin manifestations have been well described in Chile with antimicrobials occupying the first or second place of drugs involved ${ }^{1,2,12-14}$.
As observed in this series, the most frequent expression is a generalized morbilliform rash without mucosal involvement and with good prognosis. Bullous lesions, mucosal involvement or skin pain indicate more infrequent and serious conditions such as SJS which can be fatal ${ }^{14,15}$. That $\mathrm{AE}$ were more associated with beta-lactams than with any other compound, simply obey to that these are the most used compounds in hospitals in Chile ${ }^{16}$.

Hepatobiliary AE were associated with the use of anti-tuberculosis drugs and appeared from the second week of prescription. This therapeutic group is the first or second in the list of compounds responsible for drug-induced liver damage and can be associated with symptoms of hepatitis, cholestasis, or mixed disorders as observed here ${ }^{3,17}$. Pyrazinamide, the compound most frequently involved in hepatitis events in cohort and case-control studies was present in all our related events ${ }^{18}$. Hepatitis associated with isoniazid seems to be explained by the accumulation of toxic metabolites, especially in slow acetylator patients or those with certain polymorphisms of the cytochromic gene P450 CYP2E1 which confer greater enzymatic activity facilitating the accumulation of toxic products ${ }^{19}$. Rifampicin-associated cholestasia appears to be explained by the interference of this compound with biliary excretion ${ }^{19}$. Hepatotoxic factors not systematically explored in this work include alcohol consumption, malnutrition, and infection with hepatitis B virus although we were able to rule out the participation of age and previous liver damage.

Carbapenems are potentially neurotoxic compounds that have been associated with seizures. The frequency of this side effect depends on the specific molecule involved, the presence of CNS disorders, kidney failure and/or high doses ${ }^{20}$ In our case, its use in patients with previous CNS pathology and kidney failure explains its development and its potential preventability especially in the case of ertapenem.

Thrombocytopenia events can be explained by alterations of thrombopoiesis (linezolid) or by an immune mechanism with production of antibodies to the antimicrobial compound-platelet surface protein ligand (vancomycin, cephalosporins, quinolones). In our patients, the nadir of this complication occurred several days after its onset $^{21,22}$. Two of the 3 events of neutropenia were 
associated with beta-lactams, compounds that have direct marrow toxicity with development of neutropenia depending on the duration of treatment and dose of the drug ${ }^{23}$. Vancomycin has also been associated with reversible neutropenia, either due to myelotoxicity or autoimmune mechanisms and after several days of administration ${ }^{24,25}$.

Although rare, colistin-associated respiratory depression was not unexpected. It is possibly explained by a reversible myopathy, either after parenteral or inhalation therapy ${ }^{26,27}$. Other neurotoxic manifestations include paresthesias and ataxia.

A relevant aspect of this work is the high percentage of potentially avoidable AE (25\%). This fraction can escalate to higher figures during active pharmacovigilance and international data indicates that between $19 \%$ and $61 \%$ of $\mathrm{AE}$ can be prevented ${ }^{2,7,9}$. In our Center, preventability was linked to medical factors underscoring the debt that exists in undergraduate and graduate medical teaching with this topic.

Except for anti-tuberculosis drug events, a low number of reports associated with ambulatory patients were observed with no reports associated to HIV/AIDS therapy. This indicates a weakness of the system to detect events associated with non-hospitalized patients in contrast with other centers ${ }^{4}$. The low number of cases prevented further research on some risk factors for specific adverse events. Despite these limitations, our work provides a detailed view of antimicrobial-related adverse events in a general hospital, which can guide the health team in its diagnosis and prevention.

\section{References}

1. Manríquez J, Andino-Navarrete R, Cataldo-Cerda K, Downey-Saldivia C, Berroeta-Mauriziano D. Reacciones cutáneas adversas a antimicrobianos sistémicos en pacientes hospitalizados: estudio transversal analítico retrospectivo. Rev Chilena Infectol 2015; 32 (1): 11-4.

2. Sánchez I, Amador C, Plaza JC, Correa G, Amador R. Impacto clínico de un sistema de farmacovigilancia activa realizado por un farmacéutico en el reporte y subnotificación de reacciones adversas a medicamentos. Rev Med Chile 2014; 142 (8): 998-1005.

3. Contreras J, Poniachick J, Planzer M, Lazarte R, Smok G, Oksenberg D, et al. Daño hepático por fármacos: características clínicas e histológicas en 33 casos. Rev Med Chile 2003; 131 (10): 1128-34.
4. Bernal F, Vásquez P, Giadalah C, Rodríguez L, Villagrán A. Incidencia de reacciones adversas a medicamentos en pacientes que inician o cambian terapia anti-retroviral. Rev Chilena Infectol 2013; 30 (5): 507-12.

5. Yang F, Chen Z, Chen SA, Zhu Q, Wang L, Xiong H, et al. Clinical profile of cutaneous adverse drug reactions: a retrospective study of 1883 hospitalized patients from 2007 to 2016 in Shanghai, China. Eur J Dermatol 2020; 30 (1): 24-31.

6. Miguel A, Azevedo LF, Araújo M, Pereira AC. Frequency of adverse drug reactions in hospitalized patients: a systematic review and meta-analysis Pharmacoepidemiol Drug Saf 2012; 21 (11): 1139-54.

7. Iftikhar S, Sarwar MR, Saqib A, Sarfraz M. Causality and preventability assessment of adverse drug reactions and adverse drug events of antibiotics among hospitalized patients: A multicenter, cross-sectional study in Lahore, Pakistan. PLoS One 2018; 13(6): e0199456.

8. Arulkumaran N, Routledge M, Schlebusch S, Lipman J, Conway Morris A. Antimicrobial-associated harm in critical care: a narrative review Intensive Care Med 2020; 46 (2): 225-35.

9. Kunac DL, Kennedy J, Austin N, Reith D. Incidence, preventability and impact of adverse drug events (ADEs) and potential ADEs in hospitalized children in New Zealand. A prospective observational cohort study. Pediatric Drugs 2009; 11 (2): 153-60.

10. WHO. Reporting and learning systems for medication errors: the role of pharmacovigilance centres. 2014. Disponible en: https://apps.who.int/iris/handle/10665/137036 [Consultado el 19 de abril de 2020].

11. Kyonen M, Folatre I, Lagos X, Vargas S. Comparación de dos métodos de evaluación de causalidad de sospechas de reacciones adversas a medicamentos (RAM). 2003-2009. Rev Med Chile 2015; 143 (7): 880-6.

12. Martínez MC, Muñoz M, Faúndez E, Saldaña A, Roldán J. Reacciones adversas a medicamentos con compromiso mucocutáneo notificadas al Instituto de Salud Pública de Chile durante el año 2013. Rev Chilena Dermatol 2015; 31 (1): 38-42.

13. Ramírez C, Faúndez E, Orellana R. Reporte de reacciones adversas a medicamentos con compromiso mucocutáneo en Hospital Clínico Universidad de Chile durante los años 2004-2010. Rev Hosp Clin Univ Chile. 2011; 22: 104-12.

14. Manriquez J, Andino-Navarrete R, Cataldo-Cerda K, Downey C, Berroeta D. Progression of drug exanthemas to serious drug eruptions: A retrospective review identifying early determinants. Australas J Dermatol 2016; 57 (3): e83-7.

15. Sawicki J, Ellis AK. Stevens-Johnson syndrome: a review 
of 14 adult cases with one fatal outcome. Ann Allergy Asthma Immunol 2013; 110 (3): 207-209.e1.

16. Fica A, Cabello A, Juliet C, Prado P, Bavestrello L. Consumo de antimicrobianos parenterales en diferentes hospitales en Chile durante el 2005. Rev Chilena Infectol 2008; 25 (6): 419-27.

17. Hernández N, Bessone F, Sánzchez A, di Pace M, Brahm J, Zapata R, et al. Profile of idiosyncratic drug induced liver injury in Latin America. An analysis of published reports. Ann Hepatol 2014; 13 (2): 231-9.

18. Chang KC, Leung CC, Yew WW, Lau TY, Tam CM. Hepatotoxicity of pyrazinamide: Cohort and case-control analyses. Am J Respir Crit Care Med 2008; 177: 1391-6.

19. Ramappa V, Aithal GP. Hepatotoxicity related to anti-tuberculosis drugs: mechanisms and management. J Clin Exp Hepatol 2013; 3 (1): 37-49.

20. Fica A, Abusada N. Seizures associated with ertapenem use in patients with CNS disorders and renal insufficiency. Scan J Infect Dis 2008, 40: 983-85.

21. Bakchoul T, Marini I. Drug-associated thrombocytopenia. Hematology Am Soc Hematol Educ Program
2018 (1): 576-83.

22. George JN, Aster RH. Drug-induced thrombocytopenia: pathogenesis, evaluation, and management. Hematology Am Soc Hematol Educ Program 2009; 153-8.

23. Peralta G, Sánchez-Santiago MB. Neutropenia secundaria a betalactámicos. Una vieja compañera olvidada. Enferm Infecc Microbiol Clin 2005; 23 (8): 485-91.

24. di Fonzo H, Villegas Gutsch M, Castroagudin A, Cabrera MV, Mazzei ME, Rueda D. Agranulocytosis induced by vancomycin. Case report and literature review. Am J Case Rep 2018; 19: 1053-6.

25. Black E, Lau TT, Ensom MH. Vancomycin-induced neutropenia: is it dose- or duration-related? Ann Pharmacother 2011; 45 (5): 629-38.

26. Fernández-Delgado E, Egea-Guerrero JJ, Freire-Aragón MD, Rivera-Fernández V, Durán-Martínez P. Insuficiencia respiratoria grave y bloqueo neuromuscular después de la administración de colistina. Medicina Intensiva 2015; 39 (7): 448-9.

27. Wahby K, Chopra T, Chandrasekar P. Intravenous and inhalational colistin-induced respiratory failure. Clin Infect Dis 2010; 50 (6): e38-40. 